\title{
Hubungan Kekuasaan antara Lembaga Adat dan Pemerintah Desa di Sulawesi Barat
}

\author{
Nur Utaminingsih ${ }^{1}$, Muh. Zikir ${ }^{2}$, Muhammad Saleh Tajuddin ${ }^{3}$ \\ Program Studi Ilmu Politik UIN Alauddin Makassar ${ }^{1,2,3}$ \\ e-mail: zikirmangngerang@gmail.com ${ }^{1}$, nur.utaminingsih@uin-alauddin.ac.id ${ }^{2}$, \\ sal_taj2001@gmail.com ${ }^{3}$
}

\begin{abstract}
Abstrak
Penelitian ini mengkaji tentang hubungan kekuasaan antara lembaga adat dan pemerintah desa dengan maksud untuk mempercepat terwujudnya kesejahteraan masyarakat dan tujuan mengoptimalkan pelayanan, pengelolaan, pembangunan dan pemberdayaan masyarakat. Penelitian ini menggunakan pendekatan kualitatif dan menggunakan teori kekuasaan,teori relasi sosial dan teori peran sosial untuk melihat relasi kekuasaan kedua entitas tersebut. Secara umum, penelitian mengungkapkan bahwa terdapat dua bentuk hubungan kekuasaan lembaga adat dan pemerintah di Desa Tubo yaitu; Pertama, hubungan simbiosis komensalisme yaitu dalam hal pembangunan dan pemberdayaan masyarakat. Kedua,hubungan konflik yaitu menginginkan adanya bantuan pemerintah dalam hal identitas adat (berupa baju adat).
\end{abstract}

Kata Kunci :

Hubungan Kekuasaan, Lembaga Adat, Pemerintah Desa

\section{PENDAHULUAN}

Seperti daerah-daerah lain, zaman prasejarah Kabupaten Majene Provinsi Sulawesi Barat pada umumnya merupakan bagian terpanjang dari keseluruhan daerah ini. Zaman prasejarah yang ditandai dengan belum ditemukannya sumbersumber tertulis, maka hanya bahan-bahan tak tertulis saja yang dapat dipergunakan untuk menyusun sejarah. Bahan-bahan tersebut yaitu benda-benda peninggalan hasil-hasil kebudayaan. ${ }^{1}$

\footnotetext{
${ }^{1}$ Darmansyah, Pidato Hari Jadi Majene Memuat Sejarah Kerajaan Sendana, Banggae,
}

Dalam sejarah berdirinya Desa Tubo berdasarkan cerita rakyat bermulah dari sebuah wilayah kerajaan yang dipimpin seorang pria yang bergelar "Talombeng Susu" yang bermukim di puncak gunung Tuwo Poang atau "Tuo Poang" yang secara harfiah yakni Tuo berarti hidup dan Poang berarti pohon, jadi Tuo Poang bermakna kehidupan yang tumbuh dengan kuat. Kala itu, Tubo merupakan salah satu kerajaan yang berpengaruh dalam jajaran kerajaan di tanah Mandar. Dengan adanya

Pamboang dan Puraloa di Malunda' Ulumanda' (Majene: Pemda Majene, MSI Cab. Sulbar dan Tim Keratif Rumpita, 2018), h. 1. 
pusat kekuasaan kerajaan Tubo yang ada di bukit Tuo Poang dan menyebar kekuasan di pesisir barat yang sekarang terdapat di perkampungan yang dihimpit oleh gunung dan laut yaitu kampung Tubo. Hingga saat ini mempunyai kelembagaan adat yang masih berjalan dan mengikat yang secara terstruktur "Lembaga Adat Tuo Tubo" yang terdapat beberapa pemangku adat di dalamnya.

Awalnya Tubo bernama pemerintahan Distrik Tubo, kemudian pada tahun 1966 berganti nama menjadi Desa Tubo hingga sekarang. Sejak terbentuknya Desa Tubo pada tahun 1966 tersebut, Desa Tubo telah mengalami 12 kali pergantian kepala desa hingga sekarang ini yang kini dijabat Muh. Nasri untuk periode 2020 - 2026.

Melalui hubungan kerjasama antara penguasa dan masyarakat, kita patut bersyukur dengan adanya komunitas masyarakat yang sangat menjunjung tinggi kearifan lokal dalam keseharian mereka. Komunitas masyarakat tersebut adalah masyarakat tradisional atau sering disebut masyarakat adat.

Kedudukan masyarakat adat sendiri, oleh Negara telah diakui secara konstitusional yaitu dalam perubahan kedua UUD 1945 pada Pasal 18B yang berbunyi :
1. Negara mengakui
dan menghormati satuan-satuan pemerintahan daerah yang bersifat khusus atau bersifat istimewa yang diatur dengan undang-undang.
2. Negara mengakui dan menghormati kesatuan-kesatuan

masyarakat hukum adat serta hak hak tradisionalnya sepanjang masih hidup dan sesuai dengan perkembangan masyarakat dan prinsip Negara Kesatuan Republik Indonesia, yang diatur dalam undang-undang. ${ }^{2}$

Pada kelompok masyarakat tradisional, mereka memiliki kecenderungan untuk mempertahankan eksistensi nilai-nilai kemanusiaan yang di dalamnya terdapat nilai-nilai kebudayaan, tradisi dan kepercayaan-keparcayaan dari leluhur yang dijadikan falsafah hidup. Hal ini terlihat pada masyarakat Desa Tubo di tengah perkembangan zaman dan bentuk pemerintahan yang modern. Walaupun sebelum merdeka masih menggunakan sistem monarki yang mengharuskan masyarakat yang dinaungi kerajaan harus patuh dan taat pada aturan dan tradisitradisi yang berlaku, namun pasca kemerdekaan hal itu masih dapat kita jumpai dalam masyarakat adat Tubo yang bertahan hingga saat ini yang mana mereka masih menjunjung tinggi nilainilai adat dan budaya yang ditinggalkan oleh para pendahulunya di era modern ini, dan masih terdapat beberapa kesetiaan terhadap nilai-nilai dan tradisi dan para pemangku adat yang berada di tengah sistem pemerintahan desa.

Tubo saat ini meskipun sudah jadi pemerintahan desa yang secara konstitusi sudah diatur oleh negara, namun ada

${ }^{2}$ Republik Indonesia, Undang-Undang Dasar 1945, bab VI, Pasal 18B. 
beberapa relasi dan peran sosial lembaga adat dan pemerintah yang dibangun. Dari uraian latar belakang masalah yang telah dideskripsikan pada pembahasan di atas, memberikan gambaran bahwasanya fokus masalah yang dijadikan kajian dalam penelitian ini adalah bagaimana hubungan kekuasaan antara lembaga adat dan pemerintah di Desa Tubo?.

\section{KAJIAN PUSTAKA}

Kajian tentang adat, lembaga adat maupun masyarakat adat sudah banyak dilakukan oleh peneliti sebelumnya, baik dari studi sosiologi, antropologi, hukum maupun studi politik. Beberapa referensi dan kajian peneliti telusuri dari penulis lain misalnya tulisan Sitti Rosdiana. Dalam penelitiannya mengemukakan bahwa relasi masyarakat adat dan pemerintah di kelurahan Bulutana yaitu terdapat beberapa aspek dan bentuk relasi, adapun aspek yang ditimbulkan yaitu mengenai pemilihan legislatif. Adapun bentuk relasi ialah terdapat relasi simbiosis mutualisme dalam hal pembangunan dan kesejahteraan masyarakat dan juga relasi konflik yaitu dalam hal perbaikan infrastruktur adat seperti rumah adat karena adanya polemik dalam hal kepemilikan tanah adat yang bukanya menjadi hak milik negara melainkan hak milik pribadi. ${ }^{3}$

Begitupun tulisan Muvita Ayu Anjassari. Dalam tulisannya mengkaji tentang

${ }^{3}$ Sitti Rosdiana, “Adat dan Kekuasaan (Studi Terhadap Relasi Masyarakat Adat dan Pemerintah di Kelurahan Bulutana Kec. Tinggimoncong Kab. Gowa)", Skripsi (Makassar: Fak. Ushuluddin Filsafat dan Politik UIN Alauddin, 2017), h. ii. bagaimana peran lembaga adat dalam penyelenggaraan pemerintah Desa Sugihan. Meskipun lembaga adat tidak terlalu aktif dalam penyelenggaran pemerintah desa, karena antara lembaga adat dan pemerintah desa masing- masing punya kekuasaan yang berbeda, walaupun kekuasaannya yang berbeda tetapi kepala desa selalu berkoordinasi dengan kepala adat desa kesugihan, supaya pemerintah desa dan lembaga adat mengurangi adanya perseteruan keduannya yang biasanya rentang konflik dan menghindari hambatan-hambatan yang kemungkinan bisa terjadi dalam menjalankan program pemerintahan desa. Sehingga dapat dikatakan bahwa pemerintah desa sudah mampu bekerja sama dengan lembaga adat kesugihan. ${ }^{4}$

Sementara penelitian Ayu Ariskha Mutiya mengkaji tentang peranan Lembaga Adat dalam melestarikan nilai-nilai piil pesenggiri. Secara umum membicarakan tentang fungsi Lembaga Adat dalam menjaga dan melestarikan nilai-nilai kebudayaan tradisi di Desa Gunung Batin Udik. $^{5}$

${ }^{4}$ Muvita Ayu Anjassari, "Peran Lembaga Adat Dalam Penyelenggaraan Pemerintahan Desa Perspektif Hukum Islam (Studi di Desa Kesugihan Kecamatan Kalianda Kabupaten Lampung Selatan)", Skripsi (Lampung: Fak. Syari'ah UIN Raden Intan, 2019), h. 91.

${ }^{5}$ Ayu Ariskha Mutiya, "Peranan Lembaga Adat dalam Melestarikan Nilai-Nilai Piil Pesenggiri di Desa Gunung Batin Udik Kecamatan Terusan Nunnyai Kabupaten Lampung Tengah 2015", Skripsi (Bandar Lampung: Fak. Keguruan dan Ilmu Pendidikan Universitas Lampung, 2016), h. ii. 
Adapun perbedaan dari penelitian sebelumnya yaitu penulis lebih fokus pada hubungan kekuasaan antara lembaga adat dan pemerintah di Desa Tubo, Kecamatan Tubo Sendana, Kabupaten Majene, Provinsi Sulawesi Barat, dan melihat bagaimana sinergitas lembaga adat dan pemerintah desa dalam menjalankan peran sosial yang ada di Desa Tubo. Menurut penulis hubungan kekuasaan antara lembaga adat dan pemerintah desa menarik dikaji di Desa Tubo yang memiliki nilai tradisi adat yang masih di pertahankan oleh masyarakat adat dan Pemerintah Desa sebagai jalur kemitraan.

\section{TINJAUAN TEORETIS}

\section{Teori Kekuasaan}

Menurut Foucault, kekuasaan bukanlah sesuatu yang hanya dikuasai oleh negara, sesuatu yang dapat diukur. Kekuasaan ada di mana-mana, karena kekuasaan adalah satu dimensi dari relasi. Di mana ada relasi, di sana ada kekuasaan. Kuasa itu ada di mana-mana dan muncul dari relasirelasi antara pelbagai kekuatan, terjadi secara mutlak dan tidak tergantung dari kesadaran manusia. Kekuasaan hanyalah sebuah strategi. Strategi ini berlangsung di mana-mana dan di sana terdapat sistem, aturan, susunan dan regulasi. Kekuasaan ini tidak datang dari luar, melainkan kekuasaan menentukan susunan, aturan dan hubungan-hubungan dari dalam dan memungkinkan semuanya terjadi. ${ }^{6}$

${ }^{6}$ Michel Foucault, Seks dan Kekuasaan, terj. S. H. Rahayu (Jakarta: Gramedia, 2000), h. 144.

\section{Teori Relasi Sosial}

George Simmel mendefinisikan relasi sebagai sebuah konsep sosial tentang kehidupan masyarakat yang terdapat di dalamnya hubungan timbal - balik saling berinteraksi antar individu maupun kelompok yang saling berkaitan dan bekerjasama yang hidupnya bergantung pada sesama tiada lain untuk mendapatkan keseimbangan dalam kehidupan masyarakat. ${ }^{7}$ Dalam hal ini menggunakan teori relasi sosial untuk melihat bagaimana hubungan sosial antara kedua lembaga tersebut.

\section{Teori Peran Sosial}

Peran sosial adalah teori yang sering digunakan dalam dunia teater yang memakai istilah "peran" seorang aktor harus bisa memainkan karakter seorang tokoh tertentu dan dalam posisinya sebagai tokoh itu ia diharapkan untuk berperilaku secara tertentu. Teori ini sering digunakan bagi kalangan ilmu sosial sepeti halnya ilmu sosiologi dan antropologi yang masih digunakan saat ini. ${ }^{8}$ Hal ini digunakan untuk melihat bagaimana sinergitas lembaga adat dan pemerintah desa dalam menjalankan peran sosialnya di Desa Tubo.

${ }^{7}$ Kana Lailatul Ahadiyah, "Relasi Sosial Antara Kyai Non Politik dan Kyai Politik di Komunitas Religius Pedesaan", Skripsi (Surabaya: Sosiologi, Universitas Airlangga, 2018).

${ }^{8}$ Sarwono, Psikologi Sosial Individu dan Teori-Teori Psikologi Sosial (Jakarta : Balai Pustaka, 2002). 


\section{METODE PENELITIAN}

Metode penelitian yang digunakan oleh peneliti adalah metode kualiatif, yang berlokasi penelitian di Desa Tubo, Kecamatan Tubo Sendana, Kabupaten Majene, Provinsi Sulawesi Barat. Dengan menggunakan dua sumber data yaitu sumber data primer yang dilakukan melalui wawancara mendalam yang diperoleh dari narasumber atau informan dan adapun sumber data skunder yakni data yang diperoleh dari literatur-literatur studi penelitian kepustakaan melalui berbagai metode seperti membaca buku, karya tulis ilmiah, skripsi, jurnal dan berbagai lainnya yang memiliki hubungan dengan tulisan ini.

\section{PEMBAHASAN}

\section{Gambaran Umum Desa Tubo}

Desa Tubo salah satu desa di Kecamatan Tubo Sendana, Kabupaten Majene. Sebagai desa tertua di antara desa yang lain, Desa Tubo secara administratif merupakan salah satu desa induk dalam lingkup Kecamatan Tubo Sendana. Yang memiliki 6 dusun di antaranya Dusun Taraweki, Dusun Tarahoang. Dusun Salubulo, Dusun Kulasi, Dusun Kuriri dan Dusun Tarupa. Dengan pusat pemerintahan desa yang berlokasi di Dusun Salubulo.

Sejak terbentuknya Desa Tubo pada tahun 1966 Desa Tubo telah mengalami 12 kali pergantian Kepala Desa. Sekarang ini dijabat oleh Muh. Nasri untuk periode 2020-2026. Adapun secara terperinci setiap Periode Kepala Desa Tubo maupun pejabat sementara Kepala Desa sebagai berikut:

Tabel 1

Periode Kepala Desa Tubo sejak dari tahun 1966 s/d Sekarang

\begin{tabular}{|c|c|c|}
\hline No & Nama & Periode \\
\hline 1. & A. Muh. Thahir & 1966 s/d 1968 \\
\hline 2. & $\begin{array}{c}\text { M. Saleh Abu } \\
\text { Hasan }\end{array}$ & $1969 \mathrm{~s} / \mathrm{d} 1972$ \\
\hline 3. & Abd. Kadir & $1972 \mathrm{~s} / \mathrm{d} 1975$ \\
\hline 4. & Abd. Jalil & $1975 \mathrm{~s} / \mathrm{d} 1982$ \\
\hline 5. & $\begin{array}{c}\text { M. Saleh Abu } \\
\text { Hasan }\end{array}$ & $1982 \mathrm{~s} / \mathrm{d} 1985$ \\
\hline 6. & A. Muh. Thahir & $1985 \mathrm{~s} / \mathrm{d} 1990$ \\
\hline 7. & A. Muh. Thahir & $1990 \mathrm{~s} / \mathrm{d} 2000$ \\
\hline 8. & $\begin{array}{c}\text { Fadlin FK (Camat } \\
\text { Tubo Sendana): } \\
\text { Pjs. Kades Tubo }\end{array}$ & $2000 \mathrm{~s} / \mathrm{d} 2002$ \\
\hline 9. & $\begin{array}{c}\text { Hasanuddin Hapati } \\
\text { Hasan }\end{array}$ & $2002 \mathrm{~s} / \mathrm{d} 2007$ \\
\hline 10. & Muh. Nasri & $2008 \mathrm{~s} / \mathrm{d} 2014$ \\
\hline 11. & Muslimin & $2014 \mathrm{~s} / \mathrm{d} 2020$ \\
\hline 12. & Muh. Nasri & $2020 \mathrm{~s} / \mathrm{d} 2026$ \\
\hline \multicolumn{3}{|c|}{ Sumber: RPJM-Des Tubo Tahun $2020-2026$} \\
\hline
\end{tabular}

Dari tabel di atas dapat dilihat bahwa Desa Tubo merupakan desa tertua dan desa induk dari beberapa desa yang ada di Kecamatan Tubo Sendana, dengan beberapa pergantian Kepala Desa. dapat dikatakan Desa Tubo cukup berpengalaman dalam pembangunan dan kesejahteraan Masyarakat Tubo.

\section{Gambaran Sosiokultural Lembaga Adat Tubo}

Dalam sejarah berdirinya Desa Tubo berdasarkan pesan-pesan leluhur sejak ratusan tahun yang silam adalah sebuah wilayah kerajaan yang dipimpin seorang pria yang bergelar "Talombeng Susu" yang 
bermukim di puncak gunung Tuwo Poang atau "Tuo Poang" yang secara harfiah yakni Tuo berarti Hidup dan Poang berarti Batang Pohon. Jadi Tuo Poang bermakna kehidupan yang tumbuh kuat. Kala itu, Tubo salah satu merupakan kerajaan yang berpengaruh dalam jajaran kerajaan di Tanah Mandar.

Salah satu penghargaan yang diberikan kerajaan-kerajaan mandar dahulu kepada Kerajaan Tubo yaitu memberikan gelar Daeng Mattayang, juga Tubo pernah mendapatkan julukan dari Kerajaan Sendana dengan Tiga Ungkapan Pernyataan: Tubo adalah Sulo' Tappi'dena Sendana, Tubo adalah Panggambarra'na Sendana, Tubo adalah Palattokanna Sendana. Pemberian julukan ini lahir ketika Tubo turut membantu Kerajaan Sendana dalam medan pertempuran melawan serangan musuh dan rupanya kemenangan ada di pihak Kerajaan Sendana.

Salah satu keunikan dan keistimewaan yang ada di adat Tubo yaitu hingga saat ini masih menaungi 2 desa besar yang ada di dalamnya, yaitu Desa Tubo itu sendiri dan Desa Tubo Poang. Meskipun dipimpin oleh Kepala Desa yang berbeda tetapi berada dalam satu budaya adat yang sama yaitu Adat Tubo, sehingga tradisi dan kebudayaan mampu terjaga dan tetap lestari.

Tabel 2

Struktur Pemangku Lembaga Adat Tubo

\begin{tabular}{|c|c|c|c|}
\hline No & Profesi & $\begin{array}{c}\text { Tugas dan } \\
\text { Fungsi }\end{array}$ & Pemangku \\
\hline
\end{tabular}

\begin{tabular}{|c|c|c|c|}
\hline 1. & Mara'dika & $\begin{array}{c}\text { Raja/kepala } \\
\text { pemerintaha: } \\
\text { Plt Mara'dika }\end{array}$ & $\begin{array}{c}\text { H. Andi } \\
\text { Muhammad } \\
\text { Yusuf Thahir }\end{array}$ \\
\hline 2. & Baligau & $\begin{array}{c}\text { Kpl. } \\
\text { Peradilan dan } \\
\text { legislasi }\end{array}$ & $\begin{array}{c}\text { H. Ahmad } \\
\text { Sirajuddin }\end{array}$ \\
\hline 3. & Kali & $\begin{array}{c}\text { Bid. } \\
\text { Keagamaan }\end{array}$ & $\begin{array}{c}\text { Mashuri } \\
\text { Mulia }\end{array}$ \\
\hline 4. & $\begin{array}{c}\text { Pappuanga } \\
\text { n } \\
\text { Tubo } \\
\text { Ketua adat } \\
\text { dalam satu } \\
\text { wilayah }\end{array}$ & $\begin{array}{c}\text { Muh. Jafar } \\
\text { Kadir }\end{array}$ \\
\hline 5. & $\begin{array}{c}\text { Pappuanga } \\
\text { n } \\
\text { Taraweki }\end{array}$ & $\begin{array}{c}\text { Ketua adat } \\
\text { dalam satu } \\
\text { wilayah }\end{array}$ & $\begin{array}{c}\text { Khaeruddin } \\
\text { Amin }\end{array}$ \\
\hline 6. & $\begin{array}{c}\text { Pappuanga } \\
\text { n Adat } \\
\text { Sangga' } \\
\text { Kulasi }\end{array}$ & $\begin{array}{c}\text { Ketua adat } \\
\text { dalam satu } \\
\text { wilayah }\end{array}$ & Salahuddin \\
\hline 7. & $\begin{array}{c}\text { Tomatua di } \\
\text { Baturoro }\end{array}$ & $\begin{array}{c}\text { Penasehat } \\
\text { Adat }\end{array}$ & $\begin{array}{c}\text { Rahmat } \\
\text { Mangimbari }\end{array}$ \\
\hline
\end{tabular}

Sumber: RPJM-Des Tubo Tahun 2020-2026

\section{Hubungan Kekuasaan Lembaga Adat dan Pemerintah}

Mengenai hubungan lembaga adat dan pemerintah, di Indonesia mulai muncul kembali pada pasca Orde Baru, dimana sebelumnya sempat mati suri, namun eksistensinya muncul kembali pada abad XX yang ditandai dengan berbagai regulasi dan aturan yang melibatkan adat dalam pemerintahan. Dengan lahirnya Undang Undang Republik Indonesia Nomor 6 Tahun 2014 tentang Desa maka semakin memperkuat keberadaan Lembaga Adat Tubo.

\section{Hubungan Simbiosis Komensalisme}

Melihat perkembangan adat Tubo dalam hal pemerintahan saat ini sudah banyak mengalami perubahan. Seperti, ketika status Tubo yang masih pemerintahan distrik, punya wilayah kekuasaan yang luas dan sistem adat istiadat yang masih kental dalam menjalankan roda 
pemerintahan. Namun, pada tahun 1950an pada zaman "Totande" yaitu pemberontakan di Tanah Mandar yang menghapus sistem monarki yang ada pada masyarakat adat, dan kemudian beralih menjadi pemerintahan desa pada tahun 1966. Sejak beralihnya pemerintahan distrik ke pemerintahan desa, fungsi pemerintahan dipegang langsung oleh Kepala Desa dan adat sendiri tetap ada di masyarakat namun tidak dilegalkan keberadaannya. $^{9}$

Dengan tidak adanya legalitas yang diberikan oleh pemerintah desa, terhadap lembaga adat Tubo tidak mengurangi hubungan antara keduanya, dengan samasama menginginkan masyarakat sejahtera. Pada dasarnya suatu adat dapat bertahan karena difungsikan masyarakat itu sendiri, baik tradisinya, hukum adatnya, nilai-nilai kultural yang sejalan dengan nilai-nilai kemanusiaan. Pemerintah sendiri pada dasarnya menyetujui dan mendukung penuh, nilai-nilai yang ada dalam adat istiadat itu sendiri selama tidak bertentangan dengan aturan pemerintah setempat, hukum yang berlaku dan agama yang dianut.

Menganggap lembaga adat sebagai mitra, maka pemerintah memposisikan lembaga adat dalam posisi yang sama dalam artian ketika berbicara mengenai mitra, maka kedudukannya sejajar dengan pemerintah dalam hal membantu pemerintah desa dalam pemberdayaan masyarakat. Namun,

${ }^{9}$ Andi Muh Yusuf Thahir (48 Tahun), Plt Mara'dika dalam Pemangku Lembaga Adat Tubo, Wawancara, Mamuju, 22 Maret 2020. bagi lembaga adat sendiri menganggap tidak adanya legalitas yang diberikan oleh pemerintah secara tertulis itu mengurangi eksistensi adat itu sendiri.

Dalam pengembangan sumber daya manusia (SDM), kontribusi adat sangat diperlukan dalam hal pembinaan terhadap masyarakat baik dalam sosial budaya maupun dalam bidang keagamaan, karena secara keseluruhan dalam perangkat pemangku adat itu berlatar agamis, sehingga turut serta pemberdayaan adat melalui nilai-nilai keagamaan, yang tidak terlepas dari etika, adab, dan sopan santun, dalam berprilaku. Sehinggah begitu banyak dijumpai dalam masyarakat adat tradisi adat yang sejalan dengan nilai-nilai keislaman, yang mana di dalam Islam diperintahkan sikap tolong menolong, dan sikap tolong menolong itu sering dijumpai dalam tradisi masyarakat adat di Tubo.

Kemitraan lembaga adat dengan pemerintah walaupun tidak terikat secara legalitas kelembagaan, mampu mewujudkan kesejahteraan masyarakat yang ada di Desa Tubo dalam hal pembangunan. Baik itu dalam agama, sosio-kultural, SDA dan SDMnya sehingga membantu wilyah tersebut maju dan berkembang sampai saat ini.

\section{Hubungan Konflik}

Dalam hubungan masyarakat adat dan pemerintah di sini memperlihatkan adanya ketidak sepahaman antara kedua kelembagaan dengan kurangnya perhatian pemerintah terhadap adat, hal ini dapat dilihat dari kurangnya bantuan dari pemerintah. 
Dimana sejak perang mandar yang terjadi pada tahun 1950-an sampai sekarang, tidak pernah disentuh oleh pembangunan.

Sebelum Perang Mandar terjadi, situs investasi adat Tubo masih lengkap mulai dari rumah adat, yang berisi benda-benda pusaka, lontra-lontra, alat musik semuanya dibakar dan disita oleh para pemberontak "Totande". Karena itu, lembaga adat mengiginkan adanya bantuan dari pemerintah.

Andi Muhammad Yusuf Thahir dalam hal ini Plt. Mara'dika Tubo mengatakan, menyangkut dengan situs sejarah peninggalan kita kan sudah tidak ada lagi, yang sekarang masih bertahan itu lembaganya, mulai dari ketika perang mandar "Totande" sampai sekarang tidak ada yang ditinggalkan berupa materi ataupun bentuk fisik, makanya kemarin pemerintahan sebelumya saya sampaikan kepada Kepala Desa, tolong kami dibuatkan identitas kelembagaan adat, berupa kostum baju adat saja supaya kami juga punya identitas, jadi kalau ketika kami pergi di forum, acara-acara kebesaran itu kami nampak, supaya juga nantinya jelas mana pemangku adat, tapi sampai sekarang bantuan itu belum ada, saya tidak tau pemerintahan baru ini mudahmudahan ada bantuan yang diberikan kepada kami. ${ }^{10}$

Mendengar pernyataan Mara'dika Tubo, membuat penelitipun semakin tertarik untuk mengetahui lebih dalam hubungan antara keduanya, karena identitas adat juga penting dalam memperkenalkan lembaga

\footnotetext{
${ }^{10}$ Andi Muh Yusuf Thahir (48 Tahun), 22 Maret 2020.
}

adat, jika identitas adat itu hilang akan berdampak pada marwah adat Tubo itu sendiri. Melihat hal tersebut, tentu peran negara dalam hal pemerintah sangat diperlukan kontribusinya dalam bentuk bantuan.

Kepala Desa Tubo menjelaskan bahwasanya mengenai bantuan terhadap lembaga adat dalam bentuk fisik bangunan, rumah adat belum ada, tetapi dalam bentuk sarana dan prasana sudah ada yaitu memfasilitasi biaya operasional dan apa lagi ini sebenarnya kita baru memulai pekerjaan dalam hal pemerintahan yang baru, tapi kami usahakan nantinya kami bisa berkomunikasi dengan lembaga adat apa-apa keperluannya, dan juga terkait dengan permintaan kostum baju adat itu kami belum jalankan karena ada alasanalasan tertentu tapi nanti kami usahakan ada bantuan tersebut. ${ }^{11}$

Melihat konflik hubungan lembaga adat dan pemerintah dalam hal permintaan bantuan identitas adat, menurut penulis sangat penting didalamnya kehadiran negara (pemerintah) untuk ikut serta dalam membantu masyarakat adat dalam hal menjaga marwah adat itu sendiri dalam artian memberikan perhatian terhadap adat melalui bantuan-bantuan, karena aset atau peninggalan investasi adat itu sudah tidak ada, jadi adanya permintaan lembaga adat berupa kostum adat bisa memberikan identitas terhadap lembaga adat, dengan kata lain memperkenalkan kepada

\footnotetext{
${ }^{11}$ Muh. Nasri (44 Tahun), Kepala Desa Tubo, wawancara, Kantor Desa Tubo, 10 Maret 2020.
} 
masyarakat bahwa adat yang ada di Tubo masih hidup dan masih ada.

Sinergitas Lembaga Adat dan Pemerintah dalam Menjalankan Peran Sosial di Desa Tubo

Antara lembaga adat dan pemerintah di desa Tubo sangat birsinergi dalam hal menjalankan peran sosialnya yaitu membangun masyarakat yang sejahtera salah satunya yang dijalankan adalah menjaga tradisi, yang sesuai dengan perkembangan masyarakat adat dan taat terhadap aturan yang ada. Pemerintah sangat mendukung segala bentuk peran lembaga adat, oleh karena itu berikut ini beberapa peran yang dilakukan oleh pemerintah dalam mempertahankan tradisi yang ada di desa Tubo.

\section{Melestraikan Tradisi Setempat}

Tradisi sendiri dengan kata lain adalah kebiasaan orang terdahulu yang turun temurun dari nenek moyang yang masih dijalankan oleh masyarakat. Dengan demikian, adapun beberapa tradisi yang masih di jalankan oleh masyrakat adat Tubo dan pemerintah dalam menjalankan peran sosialnya.

\section{a. Makkala'tigi}

Makkala'tigi adalah salah satu rutinitas acara adat yang dilakukan masyarakat adat Tubo setiap dalam upacara pernikahan. Acara adat tersebut dihadiri oleh semua pemangku adat, dimana masing-masing melakukan tugas yang sama yaitu "Macco'bo' $i$ " dengan memberikan penanda dari jenis tumbuhan, daun pacar yang dilaksanakan di rumah masing- masing mempelai laki-laki atau perempuan.

Dalam acara makkala'tigi ini itu tidak sembarang dilaksanakan pada masyarakat umumnya, tetapi yang melaksanakannya yaitu berdasarkan yang punya garis keturunan pemangku adat, dan juga berdasarkan dengan Sorong (Mahar) yang memenuhi kriteria. Adapun kriterianya yaitu: Sorong $50=10$ Pohon Kelapa; Sorong $100=20$ Pohon Kelapa; Sorong $150=30$ Pohon Kelapa; Sorong $200=40$ Pohon Kelapa. ${ }^{12}$

Dalam tradisi makkala'tigi ini adalah suatu bentuk senergitas yang dibangun antara pemerintah dan lembaga adat dalam menjalankan peran sosial, dimana penulis jumpai ketika adanya prosesi pernikahan ritual makkala'tigi selalu dilaksanakan oleh masyarakat adat Tubo yang dimana dihadiri oleh beberapa pemangku adat yang punya wewenang untuk menjalankan proses makkala'tigi tersebut. Tradisi ini adalah suatu keharusan bagi masyarakat adat Tubo dimana penulis tidak pernah menjumpai adanya proses pernikahan yang terdapat di Desa Tubo umumnya yang tidak melaksanakan kegiatan ritual makkala'tigi.

\section{b. Mambangong Sapo}

Mambangong sapo (membangun rumah) adalah salah satu tradisi masyarakat Tubo yang masih dipertahankan saat ini, dalam mambangong sapo itu dilaksankan secara gotong royong, yang dihadiri dari

${ }^{12}$ Salahuddin (97 Tahun), Pappuangan Adat Sangga' Kulasi dalam Pemangku Lembaga Adat Tubo, wawancara, Salubulo, 14 Maret 2020. 
beberapa masyarakat, laki-laki dan perempuan. Bagi laki-lakinya yaitu membantu menarik kerangka rumah, dan perempuannya membawa makanan berupa kue dan lain-lain. Dalam mampata'dang sapo atau mendirikan rumah, itu dilaksanakan beberapa ritual dari Sanro tukang (kepala tukang) dengan beberapa perlengkapan di antaranya; buah pisang satu tandang, kelapa bertunas satu buah, tebuh satu batang, benderah merah putih dan tumbuh-tumbuhan lain yang diletakan pada tiang tengah rumah, dalam perlengkapan tersebut masing-masing punya makna filosofi yang mendalam.

Tradisi mambangong sapo selain dari keharusan bagi setiap orang dalam berumah tangga juga terdapat bentuk peran sosial di dalamnya yang dijalankan masyarakat adat dan pemerintah dengan tujuan saling membantu dan tolong menolong dalam mengikat tali persaudaraan antara sesama.

\section{c. Mambaca-Baca}

Mambaca-baca dalam istilah yaitu berdo'a untuk keselamatan, tradisi ini dilaksanakan dalam bentuk kekeluargaan maupun dalam bentuk sosial kemasyarakatan. Mambacabaca kerap kali dilaksanakan ketika seseorang sudah meninggal. Dalam tradisi mambaca-baca dihadiri tokoh agama, tokoh masyarakat, pemangku adat maupun pemerintah yang turut hadir dalam mendo'akan keselamatan orang yang meninggal.

Hal ini disampaikan Baligau Tubo melalui wawancara dengan penulis. Salah satu bentuk peran sosial yang masih kita jalankan yaitu menjaga tradisi leluhur, salah satunya adalah mambaca-baca tomate (mendoakan keselamatan orang yang meninggal) dalam tradisi ini masyarakat adat Tubo saling membantu dalam hal meringankan beban sih tuan rumah, yakni masing-masing membawa makanan berupa kande-kande (kue) untuk dimakan bersama. ${ }^{13}$

Mengenai dengan tradisi di atas bagaimana menjaling kebersamaan dan saling tolong menolong antara sesama, membantu beban keluarga yang sedang ditinggalkan, dan mengharap keselamatan bagi orang yang meninggal.

\section{d. Massiara di Ku'bu Salamaq'}

Salah satu tradisi masyarakat Tubo yang masih bertahan sampai sekarang yaitu ziarah ke makam keramat "Tuan Tosalamaq di Salubulo" (Orang Yang Selamat di Salubulu). Dalam tradisi ini diyakini bahwa "Tuan Tosalamaq" adalah orang yang selamat, selamat dunia dan akhirat. Selain dari masyarakat Tubo banyak masyarakat daerah lainnya yang berziarah ke makam ini, dengan bermacam-macam tujuan dengan meminta do'a kepada Allah melalui "Tuan Tosalamaq" dengan alasan bahwa "Tuan Tosalamaq" lebih dijabah do'anya karena orangnya yang selamat.

Menurut pernyataan tokoh agama sekaligus pengurus situs sejarah penyiar Islam makam Tuan Tosalamaq Salubulo

\footnotetext{
${ }^{13}$ Ahmad Sirajuddin (62 Tahun), Baligau dalam Pemangku Lembaga Adat Tubo, wawancara, Salutambung, 15 Maret 2020.
} 
mengatakan, dalam tradisi ini tidak terlepas dari kebiasaan leluhur kita dimana pekuburan keramat Tuan Tosalamaq dijadikan sebagai objek situs kebudayaan Islam bagi masyarakat umum. Pekuburan ini sudah lama di ziarahi oleh masyarakat umum di Desa Tubo maupun yang di luar daerah yang diyakini sebagai nenek moyang leluhur yang punya keberkahan dan kekaromahan. Olehnya itu banyak masyarakat yang berziarah dengan beberapa tujuan, ada yang berupa hajad dan lain-lain. ${ }^{14}$

Olehnya itu pekuburan Tuan Tosalamaq dijadikan sebagai situs kebudayaan Islam bagi masyarakat adat Tubo dan pemerintah karena diyakini Tuan Tosalamaq atau To patindo di Salubulo adalah nenek moyang leluhur masyarakat Tubo yang perlu dijaga dan di pertahankan.

\section{e. Hukum Adat}

Hukum adat pada dasarnya berasal dari hukum alam dimana ketika hukum adat tersebut ada yang dilanggar akan berdampak pada kerusakan sumber daya alam dan suber daya manusia, sehingga masyarakat adat Tubo sangat mematuhi hukum adat yang berlaku, baik yang terkait dengan keadaan sosial maupun dalam bentuk lingkungan karena jika sudah dikena hukum adat maka sangat sulit untuk memperbaikinya kembali.

Masyarakat adat Tubo sangat menjunjung tinggi nilai-nilai adat istiadat olehnya itu

\footnotetext{
${ }^{14}$ Suardi (73 Tahun), Tokoh Agama, Wawancara, Kulasi, 12 Maret 2020.
}

terkait dengan hukum adat, ada yang dinamakan istilah hukum Talli' yaitu hukum paksa yang diberlakukan dalam lingkup masyarakat adat Tubo termasuk pemangku adat. Hukum talli' dijatuhkan kepada setiap masyarakat adat atau pemangku adat ketika melakukan kesalahan fatal, misalnya sikondongang (kawin lari). Konsekuensinya dikeluarkan dari adat dan tidak bisa ma'gau (ikut) dalam kegiatan yang terkait dengan acara adat.

Hukum talli' tidak terlepas dari budaya dan nilai adat istiadat yang menjunjung tinggi nilai budaya siri' dengan itu masyarakat adat Tubo sangat menjaga kehormatan dan martabat nama baik keluarganya, karena akan berefek pada keturunannya. Siri' (Sikondongang) adalah aib besar yang merusak citra yang ada dalam keluarga. Adanya permasalahan sosial seperti Sikondongan itu diproses dalam hukum adat dan pemerintah sebagai saksinya, namun pemerintah tetap ikut andil dalam memberikan arahan dan respon terhadap adat selama tidak main hakim sendiri dan melanggar aturan pemerintah.

\section{Harmonisasi Masyarakat}

Peran sosial adat dan pemerintah dalam mempertahankan tradisi yang ada, yaitu salah satunya dengan mempererat hubungan harmonis antara lembaga adat Tubo dan pemerintah. Hal tersebut terlihat dan terlaksana dalam hubungan sosialnya. Sifat saling menghormati dan menghargai satu sama lain adalah hal yang utama dalam menjaling hubungan antara lembaga 
adat dan pemerintah. Dapat kita lihat dalam berbagai acara adat, pemerintah selalu ikut berpartisipasi dalam setiap acara tersebut sehingga pemerintah dekat dan tahu tentang masyarakatnya.

Menurut salah seorang tokoh masyarakat di Desa Tubo menyatakan bahwasanya membangun keharmonisan di masyarakat itu tidak terlepas dari peran sosial adat dan pemerintah, dimana saling bekerjasama dalam hal membangun hubungan emosional antara sesama. Olehnya itu masyarakat bisa merasakan dengan adanya beberapa kegiatan baik acara adat maupun acara pemerintah dalam hal saling menumbuhkan kekompakan dan keber-samaan dalam menjaling keharmonisan di dalamnya. ${ }^{15}$

Hal tersebut mendukung Prinsip dan Motto Pemerintah Desa dan Lembaga Adat Tubo dalam menjalankan kekuasaannya dengan mengikat masyarakat patuh dan taat pada aturan yang ada dan turut dalam menjaga nilai-nilai budaya dan adat istiadat. Adapun "Motto" Pemerintah Desa Tubo, yaitu:

Pertama, Sipakainga'. Saling mengingatkan apabila ada kekeliruan dalam bertindak dan juga menjadi wujud saling meng-hormati dan memuliakan.

Kedua, Sipatuo. Saling memberi jalan hidup dimana kita saling membantu satu sama lain.

\footnotetext{
${ }^{15}$ Ahmad K (67 Tahun), Tokoh Masyarakat, wawancara, Salubulo, 18 Maret 2020.
}

Ketiga, Siammasei. Saling mendo'akan dan menyayangi serta menumbuhkan sifat dan sikap saling mendo'akan keselamatan dunia maupun akhirat guna terciptanya kebersamaan dan kekeluargaan.

Keempat, Sipakalaq'bi. Sifat saling menghargai dan menghormati sesama manusia.

Adapun prinsip Lembaga Adat Tubo :

Pertama, Malilu Sipakainga'. Saling mengingatkan ketika sedang lalai apabila di antara kita ada kekeliruan dalam bertindak melakukan kesalahan, perlu adanya saling mengingatkan. Dan juga menjadi wujud saling menghormati dan memuliakan.

Kedua, Mara'ba Sipatokko. Saling memperbaiki dan menguatkan tali persaudaraan antara sesama dalam artian saling bahu membahu, dalam membangun masyarakat yang berkemajemukan dan toleran antara sesama.

Ketiga, Lolong Siparappe. Sikap solidaritas yang tinggi, seperti halnya ketika ada masalah sama-sama berjuang dalam kebenaran dan sama-sama binasa dalam perlawanan.

Keempat, Manus Siorongngi yaitu sikap saling tolong menolong ketika ada di antaranya yang mengalami musibah samasama membantu dalam menye-lamatkan dan meringankan beban yang terkena musibah. 
Kebersihan Lingkungan

Dalam hal kebersihan lingkungan tidak terlepas dari peran adat melalui gotong royong. Tubo kerap kali mendapatkan prestasi dari lomba desa mulai tingkat kecamatan sampai kabupaten. Hal ini dapat dilihat dari beberapa prestasi yang di dapatkan. Pada tahun 2013 Desa Tubo mendapatkan juara 1 lomba desa dalam hal kebersihan lingkungan dan keterampilan bekerja tingkat Kabupaten Majene, dan pada tahun yang sama di tingkat Provinsi Sulawesi Barat mendapatkan juara 3 sebagai desa yang bersih dan terampil dalam bekerja.

Menurut Baligau Tubo, bahwasanya dalam hal tradisi gotong royong itu adalah salah satu titipan nilai adat istiadat yang masih dipertahankan sampai sekarang. Dengan adanya program adat dan program desa itu ada kesamaan dalam hal gotong royong. Olehnya itu ketika pemerintah melakukan kerja bakti, dalam hal menjaga kebersihan lingkungan, adat selalu ikut berperan di dalamnya yaitu menggerakkan seтиa elemen masyarakat untuk ikut berpartisipasi. Jadi, ketika ada sebuah lomba desa yang diadakan pemerintah daerah tentu penilaiannya tidak terlepas bagaimana hubungan kerjasama antara pemerintah desa dan lembaga adat dalam menata kearifan lokal dan kebersihan lingkungan yang ada. Oleh sebabnya itu adat sangat berperan dalam menjaga kebersihan lingkungan. ${ }^{16}$

Salah satu kebanggaan desa Tubo dan keberhasilannya pernah menjadi perwakilan Kecamatan Tubo Sendana pada lomba

\footnotetext{
${ }^{16}$ Ahmad Sirajuddin, 15 Maret 2020.
}

desa bersih tingkat Kabupaten dan Provinsi.

\section{Regenerasi Adat dalam Perkembangan Adat Tubo}

Dalam era globalisasi ini peran pemuda sangat dibutukan di tengah-tengah masyarakat. Ketika pemudanya bermasa bodoh dan acuh maka hal tersebut akan meruntuhkan suatu wilayah tersebut. Oleh sebabnya sebagai pemuda harus mampu menjaga kemajuan wilayah dan kearifan lokal yang ada di daerahnya. Hal tersebut juga sangat dibutuhkan masyarakat adat Tubo, dimana karena adanya adat yang berkembang saat ini dan akan termakan oleh zaman seiring berjalannya waktu ketika tidak ada generasi muda yang berpartisipasi dan menjaganya.

Hal ini perlu penulis bahas dengan melihat hubungan pemuda dalam adat Tubo yang sangat minim sehingga dapat mengakibatkan terkikisnya berbagai situs dan informasi sejarah yang ada pada adat Tubo. Ini terlihat dari kurangnya partisipasi pemuda dalam berbagai kegiatankegiatan adat yang penulis amati.

\section{Adat dan Moderenisasi dalam Generasi} Muda Adat Tubo

Desa Tubo memiliki generasi muda sangat banyak namun di antara mereka kebanyakan tidak tertarik dalam dunia pendidikan sehingga mengakibatkan banyaknya generasi muda yang memiliki pendidikan yang rendah. Namun salah satu keunggulannya, mereka selalu berkumpul dan bergabung kemudian rajin membantu masyarkat 
dalam hal gotong royong. Mayoritas pemuda ini sering berkumpul di malam harinya namun mereka memiliki sikap tertutup dan apatis dalam keikutsertaan terhadap berbagai kejadian yang terjadi di masyarakat. Terlebih lagi ketika berbicara mengenai adat Tubo. Mereka hanya tahu keberadaan adat ketika melihat acara pernikahan, namun ketika ditanya mengenai adat Tubo mereka tidak tahu.

Sebagaimana pernyataan salah satu pemuda adat Tubo, bahwa keterlibatan pemuda mengenai adat Tubo sangatlah kurang disebabkan karena kurangnya partisipasi lembaga adat maupun pemerintah desa terhadap pemuda. Harusnya ketika melakukan suatu kegiatan atau rapat itu pemuda harus dilibatkan supaya kami dari pemuda bisa mengetahui apaapa yang perlu dijalankan sebagai pemuda, tapi nyatanya toh sampai sekarang itu tidak ada dan mengenai dengan adat Tubo kami sebagai pemuda hanya tau kalau adat Tubo itu masih ada tapi kami tidak tahu menahu secara jelas tentang sejarahnya adat Tubo. ${ }^{17}$

Dari informasi yang di dapatkan penulis di atas, pemuda adat Tubo menjadi regenerasi yang cenderung tidak terwaris-kan oleh adat Tubo karena kurangnya pemahaman tentang sejarah dan nilai kebudayaan adat istiadat.

Partisipasi Pemuda dalam Adat Tubo

Partisipasi pemuda dalam adat Tubo sangatlah rendah, dikarenakan minimnya tingkat kesadaran pribadi maupun

${ }^{17}$ Irfan Saputra (24 Tahun), Pemuda Simpatisan Adat, wawancara, Kulasi, 13 Maret 2020 . kelompok. Hal ini dikarenakan kurangnya sentuhan moril dari lembaga adat maupun pemerintahan dan kurangnya keterbukaan adat dalam membuka tabir sejarah yang ada dalam adat Tubo. Pemuda sangatlah aktif dalam hal gotong royong tetapi dalam hal partisipasi ikut dalam acara adat sangatlah kurang.

Sebagaimana dikatakan oleh Roni Mahfud. Partisipasi pemuda di Desa Tubo sangatlah kurang, dikarenakan kurangnya pemahaman yang mendalam tentang adat yang diberikan orang tua kita terdahulu sampai sekarang kepada generasi muda. Harusnya pemahaman tentang adat itu harus diceritakan kepada keturunanketurunannya supaya generasi ke generasi bisa kita dapatkan pemahaman itu, dan bisa kita ceritakan kepada generasi kita mendatang bahwa adat Tubo itu ada dan nyata. Padahal kalau kita lihat hampir setiap bulan kita melihat tradisi-tradisi adat dilaksanakan setiap ada acara pernikahan, acara adat lainnya yang justru di situ adat dan pemerintah bisa mengikutsertakan pemuda berpartisipasi dan diberikan pemahaman. ${ }^{18}$

Terdapat banyaknya acara adat yang bisa diberikan pemahaman kepada generasi muda termasuk pada Acara Makkala'tigi dimana acara tersebut selalu dilaksanakan setiap ada pernikahan yang dihadiri seluruh pemangku adat dan masyarakat setempat untuk menyaksikan ritual tersebut. Namun, acara ini penulis melihat kurangnya partisipasi pemuda dalam ikut serta acara tersebut.

\footnotetext{
${ }^{18}$ Roni Mahfud (25 Tahun), Tokoh Pemuda, wawancara, Salubulo, 16 Maret 2020.
} 
Pemuda adat Tubo dapat digolongkan pemuda yang simpati terhadap adat namun keterbatasan pemahaman tentang sejarah kebudayaan adat Tubo dan tidak adanya keterbukaan adat maupun pemerintah membuat pemuda hanya mengetahui adat Tubo ada, tetapi peran pemuda sangatlah kurang dalam ke ikutsertaan acara adat tersebut. Dengan minimya pengetahuan dan kurangnya pemahaman membuat penulis kesulitan dalam mencari informan yang kenal dan tahu tentang adat Tubo dan sejarahnya.

\section{PENUTUP}

Mengenai hubungan lembaga adat dan pemerintah, di Indonesia mulai muncul kembali pada pasca Orde Baru. UndangUndang Dasar Negara RI Tahun 1945 dan perubahan kedua pada pasal 18B yang menjelaskan tentang hubungan negara dan pengakuannya atas adat. Kemudian lahirnya Undang Undang Republik Indonesia Nomor 6 Tahun 2014 tentang desa maka semakin memperkuat keberadaan lembaga adat sebagaimana diatur lembaga kemasyarakatan desa dan lembaga adat desa yang bertugas membantu Pemerintah Desa dan sebagai mitra dalam memberdayakan, melestarikan, dan mengembangkan adat istiadat sebagai wujud pengakuan terhadap adat istiadat masyarakat desa.

\section{DAFTAR PUSTAKA}

Ayu Ariskha Mutiya, "Peranan Lembaga Adat dalam Melestarikan Nilai-Nilai Piil Pesenggiri di Desa Gunung Batin Udik Kecamatan Terusan Nunnyai Kabupaten Lampung Tengah 2015", Skripsi (Bandar Lampung: Fak. Keguruan dan Ilmu Pendidikan Universitas Lampung, 2016).

Darmansyah, Pidato Hari Jadi Majene Memuat Sejarah Kerajaan Sendana, Banggae, Pamboang dan Puraloa di Malunda' Ulumanda'(Majene: Pemda Majene, MSI Cab. Sulbar dan Tim Keratif Rumpita, 2018).

Kana Lailatul Ahadiyah, "Relasi Sosial Antara Kyai Non Politik dan Kyai Politik di Komunitas Religius Pedesaan", Skripsi (Surabaya: Sosiologi, Universitas Airlangga, 2018).

Michel Foucault, Seks dan Kekuasaan, terj. S. H. Rahayu (Jakarta: Gramedia, 2000).

Muvita Ayu Anjassari, "Peran Lembaga Adat Dalam Penyelenggaraan Pemerintahan Desa Perspektif Hukum Islam (Studi di Desa Kesugihan Kecamatan Kalianda Kabupaten Lampung Selatan)", Skripsi (Lampung: Fak. Syari'ah UIN Raden Intan, 2019).

Sarwono, Psikologi Sosial Individu dan Teori-Teori Psikologi Sosial (Jakarta : Balai Pustaka, 2002).

Sitti Rosdiana, "Adat dan Kekuasaan (Studi Terhadap Relasi Masyarakat Adat dan Pemerintah di Kelurahan Bulutana Kec. Tinggimoncong Kab. 
Gowa)", Skripsi (Makassar: Fak. Ushuluddin Filsafat dan Politik UIN Alauddin, 2017).

\section{Wawancara}

Ahmad K (67 Tahun), Tokoh Masyarakat, wawancara, Salubulo, 18 Maret 2020.

Ahmad Sirajuddin (62 Tahun), Baligau dalam Pemangku Lembaga Adat Tubo, wawancara, Salutambung, 15 Maret 2020.

Andi Muh Yusuf Thahir (48 Tahun), Plt Mara'dika dalam Pemangku Lembaga Adat Tubo, wawancara, Mamuju, 22 Maret 2020.

Irfan Saputra (24 Tahun), Pemuda Simpatisan Adat, wawancara, Kulasi, 13 Maret 2020.

Muh. Nasri (44 Tahun), Kepala Desa Tubo, wawancara, Kantor Desa Tubo, 10 Maret 2020.

Roni Mahfud (25 Tahun), Tokoh Pemuda, wawancara, Salubulo, 16 Maret 2020.

Salahuddin (97 Tahun), Pappuangan Adat Sangga' Kulasi dalam Pemangku Lembaga Adat Tubo, wawancara, Salubulo, 14 Maret 2020.

Suardi (73 Tahun), Tokoh Agama, Wawancara, Kulasi, 12 Maret 2020. 